\title{
Pengembangan Media Pembelajaran Berbasis Video Tutorial Praktik Pada Mata Kuliah Keselamatan Dan Kesehatan Kerja
}

\author{
Sri Haryanti ${ }^{1}$, Bambang Suwerda ${ }^{2}$ \\ ${ }^{1,2}$ Jurusan Kesehatan Lingkungan, Poltekkes Kemenkes Yogyakarta \\ sriharyanti149@gmail.com
}

\begin{abstract}
Abstrak : Media Pembelajaran merupakan salah satu cara untuk menunjang keberhasilan dalam pembelajaran. Dengan menggunakan media dapat meningkatkan motivasi peserta didik, sehingga peserta didik dapat mengoptimalkan seluruh inderanya karena terlibat aktif baik secara psikis maupun fisik. Penelitian ini bertujuan untuk dapat menghasilkan video tutorial praktik mata kuliah yang sesuai sebagai media pembelajaran. Video yang dihasilkan adalah Video Tutorial Praktik Spirometer pada mata kuliah Keselamatan dan Kesehatan Kerja (K3) bagi peserta didik Jurusan Kesehatan Lingkungan, Poltekkes Kementerian Kesehatan Yogyakarta.

Metode yang digunakan dalam penelitian ini adalah metode penelitian dan pengembangan. Penelitian pengembangan ini menggunakan model prosedur pengembangan Borg \& Gall yang disederhanakan oleh Tim Puslitjaknov (2008:11) dengan tahapan: 1) Menganalisis produk video yang akan dikembangkan, 2) Mengembangkan produk awal, 3) Validasi ahli dan revisi , 4) Pengujian uji coba lapangan skala kecil dan revisi, 5). Uji coba lapangan skala besar dan produk akhir. Lokasi penelitian dilakukan di Laboratorium Hyperkes, Jurusan Kesehatan Lingkungan.

Pelaksanaan Penelitian pada bulan Juli - September 2020. Hasil penelitian menunjukkan bahwa video Tutorial Praktik Spirometer pada mata kuliah keselamatan dan kesehatan kerja dapat digunakan sebagai media pembelajaran atau sumber belajar bagi peserta didik khususnya untuk mata kuliah K3 (Keselamatan Kesehatan Kerja) khususnya pada kegiatan praktikum. pada Jurusan Kesehatan Lingkungan dengan tingkat kelayakan sebesar 86,84 5\%.

Kata kunci: Media Pembelajaran; Video Tutorial; Mata Kuliah Praktik K3
\end{abstract}

Abstract: Learning media is one of the success factors in learning. With the media, students can be motivated, actively involved physically and psychologically, maximizing all students' senses in learning. This study aims to produce appropriate learning videos as learning media. The resulting video is a Video Instructional exercise Spirometer Practice in Occupational Safety and Health (K3) courses for students of the Department of Environmental Health, Ministry of Health, Yogyakarta. The method used in the research is the research and development method (Innovative work). This development research uses a simplified Borg and Nerve development procedure model by the Puslitjaknov Team (2008:11) with the following steps: 1) Analyzing the product to be developed, 2) Developing the initial product, 3) Expert validation and revision, 4) Field trials and small-scale revisions, 5). Large-scale field trials and final products. The research location was conducted at the Hyperkes Laboratory of the Department of Environmental Health. This research was conducted in July-September 2020. The results showed that the video Instructional exercise Spirometer Practice in occupational safety and health courses can be used as learning media or learning resources for students, especially for the K3 (Occupational Health Safety) practicum course. at the Department of Environmental Health. the feasibility level is $86.845 \%$.

Key individualized organization: Learning Media, Video Instructional exercise, K3 Practical Course 


\section{Pendahuluan}

Salah satu faktor keberhasilan pembelajaran adalah penggunaan media pembelajaran. Penggunaan media, dapat meningkatkan motivasi peserta didik serta memaksimalkan seluruh indera peserta didik dalam belajar. Kegiatan praktikum di Laboratorium Hyperkes merupakan bagian dari mata kuliah Keselamatan dan Kesehatan Kerja (K3). Astuti \& Mustadi (2014, hlm. 250) menyatakan bahwa media pembelajaran berupa film animasi dapat memberikan pengaruh positif terhadap kemampuan berbahasa peserta didik. Selain itu, media dalam pembelajaran dapat membantu peserta didik memahami materi dengan lebih cepat dan baik, sehingga pengetahuan yang diperoleh akan bertahan lama. Penggunaan video memiliki efek visual, sehingga dapat menghasilkan video tutorial yang menarik.

Kelebihan penggunaan media pembelajaran berbasis video tutorial dalam penyampaian materi akan lebih membantu peserta didik dalam memahami materi yang disampaikan oleh dosen. Hal ini dikarenakan media pembelajaran didesain lebih menarik dan peserta didik dapat menggunakan media tersebut secara mandiri saat di luar jam perkuliahan. Dengan demikian, jika multimedia pembelajaran dipilih, dikembangkan, digunakan dan dimanfaatkan secara tepat dan baik akan memberikan manfaat yang sangat besar dalam proses belajar mengajar. Oleh karena itu perlu diberikan perhatian khusus terhadap multimedia pembelajaran ini agar dapat digunakan di laboratorium Hyperkes Jurusan Kesehatan Lingkungan karena sangat membantu dosen dan memotivasi peserta didik, sehingga dapat meningkatkan prestasi belajar siswa baik secara individu maupun kelompok.

Riyana (2007:2) mengemukakan bahwa media video pembelajaran akan menjadi media yang menyajikan suara dan visual yang mengandung pesan-pesan pembelajaran hebat yang mengandung ide, standar, sistem, spekulasi, aplikasi untuk membantu memahami suatu materi pembelajaran. Susilana dan Riyana (2009: 147) menyatakan bahwa model tutorial merupakan pembelajaran melalui komputer yang mengkondisikan peserta didik untuk mengikuti alur pembelajaran yang terprogram dengan penyajian materi dan latihan soal. Pendapat diatas dapat disimpulkan bahwa video tutorial merupakan media pembelajaran yang menyampaikan pesan dalam bentuk audio dan visual yang didalamnya terdapat materi pembelajaran yang interaktif sehingga siswa dapat belajar secara mandiri yang tidak dibatasi oleh tempat.

Bavarharji, Alavi, dan Letchumanan (2014, hlm. 1) menyatakan bahwa dampak penggunaan video pembelajaran yang diberi teks lebih mudah dipahami terutama dalam penguasaan kosakata dan pengembangan kemampuan bahasa daripada pada pemahaman isi. Pernyataan ini menunjukkan bahwa penggunaan video dapat lebih mengembangkan kemampuan bahasa siswa sehingga siswa akan lebih efektif mendapatkan apa yang disampaikan.

Video tutorial merupakan teknologi yang merekam, menangkap, dan mengolah informasi dalam bentuk video berisi materi pembelajaran yang akan disampaikan kepada siswa (Desrianti, Rahardja, \& Mulyani, 2012). Video tutorial disebut juga dengan rekaman gambar langsung yang dapat digunakan sebagai alat atau media komunikasi dalam pembelajaran bagi siswa (Baharuddin, 2014). Sedangkan menurut Sari \& Siagian (2013), video tutorial dapat memberikan suasana belajar dan mengajar yang lebih menarik karena tampilan animasi yang menarik, sehingga proses pembelajaran tidak terkesan membosankan dan mudah dipahami oleh siswa. Media video tutorial yang diberikan kepada siswa memiliki karakteristik yang dapat menunjang kelancaran dalam proses pembelajaran, antara lain sebagai berikut: (1) video pembelajaran memiliki aplikasi slow motion yang berisi gerakan lambat, (2) video pembelajaran dapat digunakan oleh guru sebagai media pembelajaran yang telah dibuat atau dirancang sebelumnya, (3) gambar-gambar yang tersedia dalam video pembelajaran dapat bergerak, disertai unsur suara 180 sehingga dapat 
memberikan penjelasan yang baik kepada siswa, (4) video pembelajaran yang digunakan adalah linier, artinya komunikasi yang dilakukan guru kepada siswa secara langsung dan tatap muka, (5) video pembelajaran dapat digunakan untuk sekolah dengan jarak jauh, dan (6) media video pembelajaran menyajikan visualisasi yang dinamis (Amelia, 2015).

Peneliti memilih media pembelajaran video tutorial dengan alasan bahwa jika dibandingkan dengan teknik yang berbeda, media pembelajaran video pembelajaran dianggap dapat memberikan kebebasan kepada siswa untuk memiliki pilihan untuk terus belajar sehingga pembelajaran yang didapat peserta didik dapat lebih jelas, dan dengan menggunakan video tutorial instruksional dapat memberikan kebebasan kepada siswa untuk lebih efektif dalam pemahaman kata atau kalimat. Media pembelajaran video latihan yang diterapkan dalam pembelajaran yang layak pada mata kuliah K3 dimulai dengan penyusunan, pelaksanaan langkah-langkah yang menggarisbawahi perencanaan selama pelaksanaan.

\section{Metode Penelitian}

Penelitian yang berjudul Pengembangan Media Pembelajaran Berbasis Video Tutorial Praktik Pada Mata Kuliah Keselamatan dan Kesehatan Kerja ini menggunakan metode penelitian dan pengembangan (Research and Development). Lokasi Penelitian di Laboratorium Hyperkes Jurusan Kesehatan Lingkungan Poltekkes Kemenkes Yogyakarta. Penelitian ini menggunakan model prosedur pengembangan Borg dan Gall yang disederhanakan oleh Puslitjaknov Group (2008:11) dengan tahapan: 1) Menganalisis produk yang akan dibuat, 2) Pengembangan produk awal, 3) Validasi oleh para ahli dan revisi, 4) Uji coba secara lapangan dan revisi, 5). Uji coba lapangan skala besar dan hasil akhirnya.

Populasi dalam penelitian ini adalah semua mahasiswa Jurusan Kesehatan Lingkungan Program Studi Sarjana Terapan Sanitasi Lingkungan, sedangkan sampelnya adalah mahasiswa semester 3 program studi sarjana terapan sanitasi lingkungan sebanyak 73 mahasiswa. . Instrumen yang digunakan untuk penelitian ini meliputi Perangkat: Handycam/kamera, Hardisk/memori eksternal, fasilitas praktik di Laboratporium Hyperkes, spirometri,, Tripod, sedangkan bahannya meliputi : Kuesioner/ Angket, Formulir penilaian kelayakan media. Pengumpulan data dalam penelitian dilakukan dengan cara observasi, wawancara, serta pengisian kuesioner dengan menggunakan google form. Dalam pengumpulan informasi, instrumen yang digunakan antara lain: panduan wawancara, survei/jajak pendapat dan dokumentasi

Instrumen yang digunakan dalam penelitian pengembangan ini adalah instrument non tes. Dalam penelitian ini instrumen yang digunakan meliputi: panduan observasi, angket/kuesioner dan dokumentasi. Instrumen panduan wawancara digunakan selama penelitian untuk mencari masalah dan kebutuhan. Instrumen angket validasi digunakan pada saat persetujuan atau validasi dengan ahli media serta ahli materi. Angket respon mahasiswa sebagai pengguna diperlukan untuk penilaian terhadap kelayakan media. Penelitian ini menggunakan jenis angket tertutup. Pada angket tertutup jumlah item serta alternatif jawaban maupun respon sudah ditentukan sehingga responden hanya memilih sesuai kenyataannya (Eko Putra, 2013: 36).

Angket yang diberikan kepada ahli media dan ahli materi kemudian dinilai oleh para ahli dengan cara mengisi angket validasi . Penilaian dengan menggunakan skala Guttman sehingga didapatkan jawaban yang yang jelas (tegas) dan mantap terhadap masalah yang ditanyakan (Eko Putro, 2013: 116). Dalam penelitian ini angket validasi menggunakan skala Guttman, masingmasing item memiliki dua alternatif jawaban yaitu Ya ${ }^{e e}$ dan Tidakee. Jawaban Ya yang dipilih 
memiliki bobot skor 1, maka isi butir-butir pada instrumen tersebut dinyatakan layak. sedangkan jawaban "Tidak" memiliki bobot skor 0 yang artinya isi butir instrumen dinyatakan tidak sesuai.

Penilaian kelayakan media pembelajaran video tutorial yang telah dibuat oleh para ahli digunakan skala pengukuran dengan menggunakan skala likert. Variabel yang akan diukur diuraikan secara terperinci ke dalam variabel indikator. Kemudian, pada saat itu penanda variabel digunakan sebagai tahap awal untuk menyusun item-item instrumen yang dapat berupa pernyataan atau pertanyaan. Tanggapan terhadap setiap item instrumen yang menggunakan skala Likert memiliki tingkat dari sangat positif hingga sangat negatif. Validasi instrument dibedakan menjadi dua, yaitu validitas internal dan validitas eksternal. Instrumen tersebut memiliki validitas internal jika standar-standar yang terkandung dalam instrumen tersebut secara wajar (secara teoritis) mencerminkan apa yang telah diperkirakan. Sementara itu, instrumen yang memiliki validitas eksternal pada realitas eksperimental atau realitas di lapangan (Sugiyono, 2013: 174). Dalam penelitian lanjutan ini, validasi instrumen yang digunakan adalah validasi pengembangan (konstruk).

Pengujian validasi pengembangan dapat memanfaatkan penilaian atau pendapat ahli (expert judgement). Pakar diminta pendapatnya terhadap instrumen yang telah disusun. Para ahli akan menentukan pilihan apakah instrumen dapat digunakan untuk perbaikan, tanpa perbaikan, dan mungkin didesain ulang secara total (Eko Putro, 2013: 145). Penilaian ketercapaian media pembelajaran yang telah dilakukan oleh pakar menggunakan skala likert. Dalam penelitian ini, indikator variabel merupakan gambaran dari variabel yang akan diestimasi. Item Instrumen berupa penjelasan atau pertanyaan dari indikator variabel. Setiap instrumen memiliki jawaban menggunakan skala likert yang memiliki derajat dari sangat positif hingga sangat negatif.

Tabel berikut ini merupakan table yang digunakan untuk menentukan kelayakan dari lembar penilaian oleh para ahli dapat dilihat pada Tabel 1.

Tabel 1. Kriteria Penilaian Kelayakan oleh Para Ahli

\begin{tabular}{clc}
\hline Nilai & \multicolumn{2}{c}{ Kriteria Kualitas Penilaian } \\
\cline { 2 - 3 } & $\begin{array}{l}\text { Kategori } \\
\text { Penilaian }\end{array}$ & \multicolumn{1}{c}{ Interval Nilai } \\
\hline 1 & Layak & $\left(\mathrm{X}_{\min }+\mathrm{P}\right) \leq \mathrm{X} \leq \mathrm{X}_{\text {Maks }}$ \\
0 & Tidak Layak & $\mathrm{X}_{\min } \leq \mathrm{X} \leq\left(\mathrm{X}_{\min }+\mathrm{P}-1\right)$ \\
\hline
\end{tabular}

Keterangan:

$\mathrm{X}=$ Skor responden

$\mathrm{Xmin}=$ Skor terendah

$\mathrm{P} \quad=$ Panjang kelas interval XMaks = Skor tertinggi $($ Sukardi, 2003: 85)

Intrepretasi kategori penilaian kelayakan media video pembelajaran olah para ahli digambarkan pad tabel 8 sebagai berikut :

Untuk menafsirkan data hasil pengukuran kelayakan media video Praktik K3 oleh mahasiswa maka dibutuhkan kriteria penilaian kelayakan media video oleh siswa yang dijelaskan dalam tabel 2: 
Tabel 2. Kriteria Penilaian Kelayakan Media Video oleh mahasiswa

\begin{tabular}{lcl}
\hline Kategori Penilaian & Vilai & \multicolumn{1}{c}{ Interval Nilai } \\
\hline Sangat layak & 5 & $(\mathrm{Xmin}+4 \mathrm{P}) \leq \mathrm{X} \leq \mathrm{Xmaks}$ \\
Layak & 4 & $(\mathrm{Xmin}+3 \mathrm{P}) \leq \mathrm{X} \leq \mathrm{Xmin}+4 \mathrm{P}-1$ \\
Cukup Layak & 3 & $(\mathrm{Xmin}+2 \mathrm{P}) \leq \mathrm{X} \leq(\mathrm{Xmin}+3 \mathrm{P}-1)$ \\
Tidak Layak & 2 & $(\mathrm{Xmin}+\mathrm{P}) \leq \mathrm{X} \leq(\mathrm{Xmin}+2 \mathrm{P}-1)$ \\
Sangat Tidak & 1 & $\mathrm{Xmin} \leq \mathrm{X} \leq(\mathrm{Xmin}+\mathrm{P}-1)$ \\
Layak & & \\
\hline
\end{tabular}

Keterangan:

$\begin{array}{ll}\mathrm{X} & =\text { Skor yang telah diperoleh } \\ \mathrm{Xmin} & =\text { Skor minimum } \\ \mathrm{Xmaks} & =\text { Skor maksimum } \\ \mathrm{P} & =\text { Panjang kelas interval(Sukardi, 2003: 147) }\end{array}$

\section{Hasil dan Pembahasan}

Lokasi Penelitian ini di Laboratorium Hyperkes, Jurusan Kesehatan Lingkungan Poltekkes, Kementerian Kesehatan Yogyakarta. Penelitian ini merupakan jenis penelitian dan pengembangan. Penelitian ini bertujuan untuk menghasilkan video tutorial yang dapat digunakan sebagai media pembelajaran melalui tahap pengembangan. Penelitian pengembangan ini memanfaatkan model penelitian pengembangan yang dilakuakan oleh Borg \& Gall yang disederhanakan oleh Tim Puslitjaknov (2008:11) dengan tahapan: 1) Melakukan analisis produk yang akan dikembangkan, 2) Mengembangkan produk awal, 3) Validasi serta perbaikan dari ahli, 4 ) Uji coba lapangan skala kecil dan perbaikan, 5) Uji coba lapangan skala besar dan produk akhir. Analisis produk dalam penelitian ini dilakukan melalui 2 kegiatan yaitu review kurikulum dan studi pendahuluan produk media video. Studi pendahuluan dilakukan dengan cara observasi. Pengamatan dilakukan di laboratorium Hyperkes Jurusan Kesehatan Lingkungan dan Program Studi Sarjana Terapan Sanitasi Lingkungan.

Observasi di Laboratorium Hyperkes dilakukan dengan mengumpulkan data alat-alat praktikum khususnya untuk mata kuliah K3. Observasi di Program Studi dilakukan dengan melihat RPS (Rencana Pembelajaran Semester) dan metode yang digunakan untuk perkuliahan praktek. Studi pendahuluan dilakukan dengan cara observasi. Pengamatan dilakukan di laboratorium Hyperkes Jurusan Kesehatan Lingkungan dan Program Studi Sarjana Terapan Penyehatan Lingkungan. Media video yang telah dikembangkan sebagai produk awal kemudian diuji kelayakannya sebagai media pembelajaran. Data hasil validasi dan revisi digunakan untuk mengetahui kesesuaian media video berdasarkan kebutuhan serta pemikiran rasional. Tujuan dilakukan validasi media oleh ahli materi untuk menguji validitas atau kelayakan media video ditinjau dari aspek materi yang meliputi: relevansi materi dengan silabus, kualitas materi, bahasa, dan tipografi yang digunakan pada media video yang sedang dikembangkan. Hasil penilaian validasi media video pada mata kuliah K3 dianalisis menggunakan skala Guttman dengan dua alternatif jawaban yaitu "sesuai" dan "tidak layak". Skor untuk jawaban yang sesuai adalah 1 dan 
skor untuk jawaban yang tidak tepat adalah 0 . Item pernyataan terdiri dari 9 item dengan 1 nomor ahli. Maka diperoleh skor minimal 0 x $9=0$, dan skor maksimal 1 x 9=9, jumlah kelas 2, panjang interval 4,5 (dibulatkan 4), sehingga memenuhi kriteria kelayakan video media menurut ahli materi adalah:

Tabel 3. Penilaian Kriteria Kelayakan Media Video oleh Ahli Materi

\begin{tabular}{llll}
\hline No & Kategori & Skor & Hasil \\
\hline 1 & Layak & $(\mathrm{Xmin}+\mathrm{P}) \leq \mathrm{X} \leq \mathrm{Xmaks}$ & $5 \leq \mathrm{X} \leq 9$ \\
2 & Tidak Layak & $(\mathrm{Xmin}) \leq \mathrm{X} \leq \mathrm{Xmin}+(\mathrm{P}-1)$ & $0 \leq \mathrm{X} \leq 4$ \\
\hline
\end{tabular}

Berdasarkan tabel 3 kriteria kelayakan media video oleh ahli materi di atas maka dapat diketahui hasil validasi media video oleh ahli materi yang dapat dilihat pada Tabel 4:

Tabel 4. Hasil Penilaian Validasi Media Video oleh Ahli Materi

\begin{tabular}{ccc}
\hline Ahli Materi & Skor & Kelayakan \\
\hline Ahli 1 & 9 & Layak \\
Skor Total & 9 & Layak \\
\hline
\end{tabular}

Berdasarkan penilaian kelayakan dari kedua ahli materi tersebut, diperoleh skor umum keseluruhan 9, skor total adalah 9, sehingga jika dilihat dari tabel model kualifikasi atau kriteria kelayakan media pembelajaran video untuk mata kuliah praktik $\mathrm{K} 3$, termasuk dalam kategori "layak". Sehingga dapat disimpulkan bahwa media video untuk mata kuliah K3 ini telah memenuhi kaidah substansi materi sehingga sangat baik dapat dimanfaatkan sebagai media pembelajaran.

Pengesahan media atau validasi media dilakukan oleh ahli media yang mengevaluasi media dari aspek kapasitas dan keunggulan media, bagian visual dari media video, bagian suara dari media, sudut pandang tipografi, sudut bahasa, dan bagian pemrograman dari media video sebagai media pembelajaran. Hasil penilaian validasi media video praktik K3 dianalisis dengan menggunakan skala guttman dengan dua pilihan jawaban yaitu "layak" dan "tidak layak". Skor untuk jawaban yang layak (sesuai) adalah 1 dan skor untuk jawaban yang tidak layak adalah 0 . Butir soal atau butir pertanyaan terdiri dari 15 hal, maka skor dasarnya adalah 0 x $15=0$ dan skor terbesar adalah 1 x $15=15$, jumlah kelas adalah 1, dan panjang rentang kelas adalah 7,5 (dibulatkan =7), sehingga model kualifikasi/ kriteria kelayakan untuk media video oleh ahli media di tampilkan pada Tabel 5:

Tabel 5. Kriteria Penilaian Kelayakan Media Video oleh Ahli Media

\begin{tabular}{cccc}
\hline No & Kategori & Skor & Hasil \\
1 & Layak & $(\mathrm{Xmin}+\mathrm{P}) \leq \mathrm{X} \leq \mathrm{X}$ maks & $8 \leq \mathrm{X} \leq 15$ \\
2 & Tidak Layak & $(\mathrm{Xmin}) \leq \mathrm{X} \leq \mathrm{X}$ min $+(\mathrm{P}-1)$ & $0 \leq \mathrm{SX} \leq 7$ \\
\hline
\end{tabular}

Berdasarkan tabel 5 kriteria kelayakan media video oleh ahli media di atas maka dapat diketahui hasil validasi media video oleh ahli materi yang di tampilkan pada Tabel 6: 
Tabel 6. Hasil Penilaian Validasi Media Video oleh Ahli Media

\begin{tabular}{ccc}
\hline Ahli Materi & Skor & Kelayakan \\
\hline Ahli 1 & 10 & Layak \\
Skor Total & 10 & Layak \\
\hline
\end{tabular}

Aspek yang dinilai dalam uji coba kejelasan media video praktik untuk mata kuliah K3 pada uji coba skala kecil terdiri dari aspek fungsi/kapasitas dan keunggulan, tayangan program, bahasa, dan tipografi. Uji coba lapangan skala kecil dilakukan kepada 3 orang mahasiswa semester 7 yang sudah pernah melaksanakan praktik K3.

Berdasarkan skor data penilaian yang diujikan kepada 3 orang mahasiswa yang mengisi angket berisi 8 item pernyataan dengan penskoran jawaban sangat layak $=0$ item (skor 5), layak = 6 item (skor 4), cukup layak =2 (skor 3) tidak layak= 0 item (skor 2), dan sangat tidak layak $=0$ (skor 1 ). Perhitungannya adalah skor minimum 1 x $8=8$, dan skor maksimum $5 \times 8=40$, dengan jumlah kelas 5 dan panjang interval $(\mathrm{P})=6,2$ maka dibulatkan menjadi 6. Sehingga kriteria Kelayakan media video oleh mahasiswa sperti pada Tabel 7:

Tabel 7. Kriteria Kelayakan Media Video oleh mahasiswa pada Uji Coba Lapangan Skala Kecil

\begin{tabular}{cllc}
\hline Kelas & $\begin{array}{c}\text { Kategori } \\
\text { Penilaian }\end{array}$ & \multicolumn{1}{c}{ Interval Kelas } & $\begin{array}{c}\text { Hasil interval } \\
\text { Nilai }\end{array}$ \\
\hline 5 & Sangat Layak & $(\mathrm{Xmin}+4 \mathrm{P}) \leq \mathrm{X} \leq \mathrm{Xmaks}$ & $36 \leq \mathrm{X} \leq 40$ \\
4 & Layak & $(\mathrm{Xmin}+3 \mathrm{P}) \leq \mathrm{X} \leq \mathrm{Xmin}+4 \mathrm{P}-1)$ & $29 \leq \mathrm{X} \leq 35$ \\
3 & Cukup Layak & $(\mathrm{Xmin}+2 \mathrm{P}) \leq \mathrm{X} \leq(\mathrm{Xmin}+3 \mathrm{P}-1)$ & $22 \leq \mathrm{X} \leq 28$ \\
2 & Tidak layak & $(\mathrm{Xmin}+\mathrm{P}) \leq \mathrm{X} \leq(\mathrm{Xmin}+2 \mathrm{P}-1)$ & $15 \leq \mathrm{X} \leq 21$ \\
1 & Sangat tidak layak & $\mathrm{Xmin} \leq \mathrm{X} \leq(\mathrm{X} \min +\mathrm{P}-1)$ & $8 \leq \mathrm{X} \leq 14$ \\
\hline
\end{tabular}

Dilihat dari hasil keterbacaan media video oleh mahasiswa (responden) dalam uji coba skala kecil, cenderung terlihat bahwa skor keseluruhan adalah 30 atau dengan prosentase $75 \%$, jika dilihat pada tabel di atas, maka nilai tersebut berada pada kategori layak antara 26 $\leq \mathrm{X} \leq 35$, maka sangat baik dapat diartikan bahwa media video untuk mata kuliah K3 ini layak untuk digunakan sebagai media video pembelajaran, meskipun dengan upgrade pada rentang pemutaran video dibuat menjadi lebih lama.

Penetuan kelayakan media video untuk Pembelajaran Praktik Mata Kuliah K3 diukur melalui uji pendahuluan luas atau uji coba lapangan, khususnya uji coba tahap akhir terhadap produk media video. Uji coba ini dilakukan setelah disetujui atau divalidasi oleh ahli materi, ahli media dan uji coba lapangan skala kecil.. Uji kelayakan media video tutorial praktik K3 ini diterapkan pada 73 mahasiswa semester III Program Studi Sarjana Terapan Sanitasi Lingkungan. Aspek yang dievaluasi pada uji coba keterbacaan media video meliputi kapasitas/fungsi dan keunggulan, tayangan program, bahasa dan tipografi media video sebagai media pembelajaran. . Jumlah keseluruhan item pernyataan adalah 8 pernyataan. Responden kemudian memberikan penilaian dengan melengkapi survei melalui google form. Adapun hasilnya tersaji dalam table berikut : 
Tabel 8.

Rekapan Kuesioner Hasil Penilaian Mahasiswa Terhadap Media Video Pembelajaran Praktik K3

\begin{tabular}{llcc}
\hline No & Kategori & Skor & Jumlah Mahasiswa \\
\hline 1 & Sangat Layak & 5 & 33 \\
2 & Layak & 4 & 32 \\
3 & Cukup Layak & 3 & 7 \\
4 & Tidak Layak & 2 & 1 \\
5 & Sangat Tidak Layak & 1 & 0 \\
\multicolumn{2}{c}{ Total } & & 73 \\
\hline
\end{tabular}

Sumber : Data Primer, 2020

Dari hasil penelitian, didapatkan data mahasiswa yang memberi penilaian sangat layak sebanyak 33 mahasiswa, layak 32 mahasiswa, cukup layak 7 mahasiswa, serta tidak layak 1 mahasiswa. Apabila digambarkan dalam bentuk diagram yang dapat dilihat pada Gambar 1 :

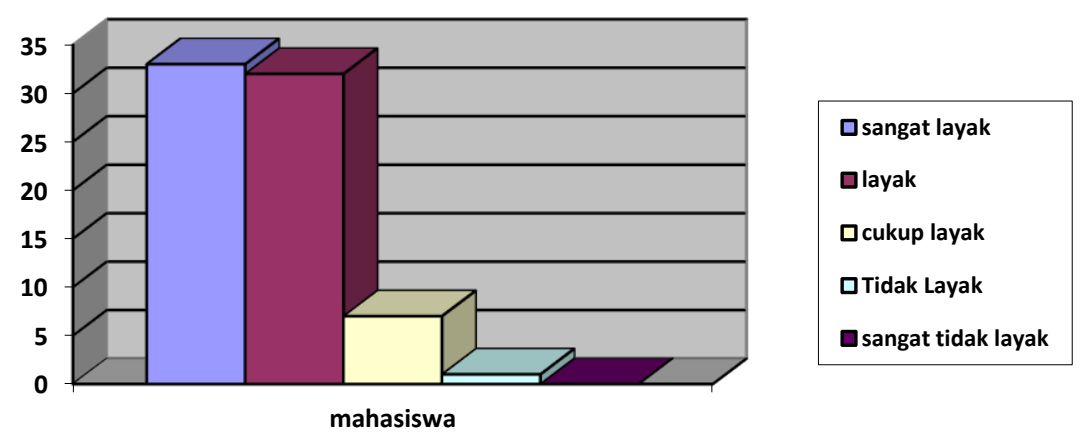

Gambar .1 Hasil penilaian mahasiswa terhadap video pembelajarann

Hasil Pengujian untuk penilaian kelayakan tersaji dalam table 9 :

Tabel 9

Hasil Pengujian penilaian kelayakan Video Pembelajaran Praktik pada Mata Kuliah K3

\begin{tabular}{cllc}
\hline Kelas & $\begin{array}{l}\text { Kategori } \\
\text { Penilaian }\end{array}$ & \multicolumn{1}{c}{ Interval Kelas } & Hasil interval Nilai \\
\hline 5 & Sangat Layak & $(\mathrm{Xmin}+4 \mathrm{P}) \leq \mathrm{X} \leq \mathrm{Xmaks}$ & $309 \leq \mathrm{X} \leq 365$ \\
4 & Layak & $(\mathrm{Xmin}+3 \mathrm{P}) \leq \mathrm{X} \leq(\mathrm{Xmin}+4 \mathrm{P}-1)$ & $250 \leq \mathrm{X} \leq 308$ \\
3 & Cukup Layak & $(\mathrm{Xmin}+2 \mathrm{P}) \leq \mathrm{X} \leq(\mathrm{Xmin}+3 \mathrm{P}-1)$ & $191 \leq \mathrm{X} \leq 249$ \\
2 & Tidak layak & $(\mathrm{Xmin}+\mathrm{P}) \leq \mathrm{X} \leq(\mathrm{Xmin}+2 \mathrm{P}-1)$ & $132 \leq \mathrm{X} \leq 190$ \\
1 & Sangat Tidak & $\mathrm{Xmin} \leq \mathrm{X} \leq(\mathrm{Xmin}+\mathrm{P}-1)$ & $73 \leq \mathrm{X} \leq 131$ \\
& layak & & \\
\hline
\end{tabular}

Sumber : Data Primer, 2020 
Jumlah Skor Hasil:

$=($ Kategori $\mathrm{x}$ hasil $)+($ kategori $\mathrm{x}$ hasil $)+($ kategori $\mathrm{x}$ hasil $)+($ kategori $\mathrm{x}$ hasil $)$

$=(5 \times 33)+(4 \times 32)+(3 \times 7)+(2 \times 1)+(1 \times 1)+(0 \times 0)$

$=315$, sehingga hasil penilaian di interval kelas $309 \leq \mathrm{S} \leq 365$ yaitu sangat layak

sekali

Persentase $(\%): 317 / 365 * 100 \%=86,84 \%$

Berdasarkan hasil penerapan media video pada uji coba luas yang diterapkan kepada 73 orang mahasiswa yang digunakan untuk menilai produk media dari aspek secara keseluruhan, maka diperoleh skor keseluruhan responden adalah 317 dengan persentase kelayakan adalah 86,84\%. Dengan demikian dapat diinterpretasikan bahwa media video pembelajaran praktik pada mata kuliah Praktik K3 ini dan dapat digunakan sebagai media pembelajaran di Jurusan Kesehatan Lingkungan Poltekkes Kemenkes Yogyakarta.

Menurut Oetomo (2002: 109), secara umum, multimedia dicirikan sebagai perpaduan antara teks, gambar, pengerjaan realistis, keaktifan, suara, dan video. Berbagai media tersebut digabungkan menjadi satu kesatuan kerja yang akan menghadirkan data yang tidak hanya dapat dilihat sebagai cetakan saja, tetapi juga dapat didengar, membentuk simulasi dan animasi yang dapat membangkitkan minat dan memiliki nilai seni yang tinggi dalam pertunjukannya. Ariani dan Haryanto (2010:25) mengemukakan bahwa multimedia dibagi menjadi dua kelas, lebih spesifiknya: multimedia linier dan multimedia interaktif.

\section{Kesimpulan}

Pengembangan Video Pembelajaran Praktik Spirometer pada Matakuliah Keselamatan Kesehatan Kerja (K3) dihasilkan melalui beberapa proses tahap yang meliputi a).Melakukan penelaahan produk yang akan dikembangkan, b) Melakukan pengembangkan terhadap produk awal, c) validasi ahli dan perbaikan kembali, d) Melakukan pengujian lapangan skala kecil dan perbaikan kembali e) Melakukan pengujian lapangan skala besar dan produk akhir. Berdasarkan hasil penilaian dari validasi ahli materi,ahli media,uji coba skala kecil serta penerapan media video pada uji coba luas yang diterapkan kepada 73 orang mahasiswa, video praktik pembelajaran matakuliah praktik ini dapat digunakan sebagai sumber belajar khususnya pada mata kuliah praktik Keselamatan dan Kesehatan Kerja (K3) dengan tingkat kelayakan 86,84 \% (sangat layak).

\section{Daftar Pustaka}

Amelia, F. (2015). Pengembangan Media Latihan Video Tutorial Teknik Dasar Tangkisan Berladiri untuk Anak Usia Dini (Kajian Teknik Taekwondo). Yogyakarta: UNY.

Ariani, N. \& Haryanto, D. (2010). Pembelajaran Multimedia di Sekolah. Jakarta: PT. Prestasi Pustakaraya.

Arsyad, A. (2007). Media Pembelajaran. Jakarta: PT Raja Grafindo Persada.

Asyhar, R. (2012). Kreatif Mengembangkan Media Pembelajaran. Jakarta: Referensi.

Astuti, Y., \& Mustadi, A. (2014). Pengaruh penggunaan media film animasi terhadap keterampilan menulis karangan narasi siswa kelas V SD.. Jurnal Prima Edukasia, 2(2), 250-262. Retrieved from http://journal.uny.ac.id/index.php/jpe/arti cle/view/2723 
Baharuddin, I. (2014). Efektivitas Penggunaan Media Video Tutorial Sebagai Pendukung Pembelajaran Matematika Terhadap Minat dan Hasil Belajar Peserta Didik SMA Negeri 1 Bajo Kabupaten Luwu Sulawesi Selatan. Jurnal Matematika, 2(2), 144-151.

Bavaharji, M., Alavi, Z. K., \& Letchumanan, K. (2014). Captioned instructional video: effects on content comprehension vocabulary acquisition and language proficiency. Canadian Center of Science and Education, 7, 1-16

Desrianti, D. I., Rahardja, U., \& Mulyani, R. (2012). Audio Visual As One Of The Teaching Resources On Ilearning. CCIT Jurnal, 5(2), 124-144.

Djamarah, S.B, dan Aswan Z. (2010). Strategi Belajar Mengajar. Jakarta: Rineka Cipta. http://multimediapembelajaran.blogspot.com/

Kurniawan, E.D, Nopriyanti, Sucipto3, S.D (2018). Pengembangan Modul Elektronik Berbasis Video Tutorial Pada Matakuliah Cad/Cam Materi Gambar 3d, Majalah Ilmiah Sriwijaya, Volume XXX, No.17, April 2018

Oetomo, B.S.D. (2002). E-education; Konsep Teknologi dan Aplikasi Internet Pendidikan. Yogyakarta: Andi.

Riyana, C. Sudjana, N. \& Rivai, A. (1991). Media Pengajaran. Bandung: Sinar Baru.

Sari, D. M., \& Siagian, S. (2013). Pengembangan Media Video Pembelajaran Pangkas Rambut Lanjutan Berbasis Komputer Program Studi Tata Rias Rambut. Jurnal Teknologi Pendidikan, 6(1), $1-15$.

Sugiyono. (2013). "Metode Penelitian Kuantitatif Kualitatif dan R\&D”. Bandung: Alfabeta.

Sugiyono. (2014). "Metode Penelitian Pendidikan Pendekatan Kuantitatif Kualitatif dan R\&D". Bandung: Alfabeta.

Susilana, R. \& Riyana, C. (2009). (2007). Pedoman Pengembangan Media Video. Bandung:

Media Pembelajaran : Hakikat, Pengembangan, Pemanfaatan, dan Penilaian. Bandung: CV. Wacana Prima. 